
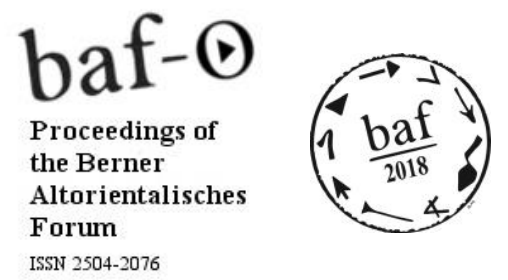

\author{
Abstract \\ Moira Looney \\ University of Bern \\ DOI: http://dx.doi.org/10.22012/baf.2018.06
}

\title{
Clay Figurines from Sirkeli Höyük
}

Sirkeli Höyük is a settlement mound in the cilician plain near Adana, Turkey. It was first excavated in the 1930s by John Garstang. Work there was resumed in the 1990s by Barthel Hrouda and Horst Ehringhaus, and then again from 2006 until the present day; initially by the Universities of Tübingen and Çanakkale and subsequently (2011 onwards) by the Universities of Bern and Çanakkale. My Master's thesis focused on the terracotta figurines unearthed during the excavations from 1992 onwards. Its aim was to construct a classification for the material from Sirkeli Höyük, which I documented, classified and catalogued according to their shape. I did not create a completely new classification, but rather tried to build on work form A. Pruss and H. Goldmann, who's approaches I adapted to suit the material from Sirkeli Höyük. The terracotta figurines found to date span the following epochs: the Hellenistic period, the Iron Age, the Late Bronze Age, and the Middle Bronze Age. The first aim of my $\mathrm{PhD}$ is to construct a working typology for these terracotta figurines by clearly defining the criteria of each of the different types. In a second phase I intend to elaborate my existing comparison of the material from Sirkeli Höyük and figurines from other excavations in the cicilian plain, to document their geographical distribution and diversity. The final phase will be an evaluation of the temporal dispersion of differing styles with a view to determining the extent of any extra-regional influences. 